\title{
Development of personalized molds for neovagina creation by 3D printer
}

\author{
Thyeres Teixeira Bueno Chrispin \\ (iD) Marina Silva Fernandez ${ }^{2}$ \\ DClaudia Cristina Takano Novoa \\ (iD) Marair Gracio Ferreira Sartori ${ }^{4}$
}

\begin{abstract}
1. Pós-graduando em Ginecologia - Escola Paulista de Medicina - Universidade Federal de São Paulo (Unifesp) - São Paulo, SP, Brasil. 2. Pós-graduanda em Uroginecologia - Escola Paulista de Medicina - Universidade Federal de São Paulo (Unifesp) - São Paulo, SP, Brasil. 3. Doutora em Ginecologia e Obstetrícia Escola Paulista de Medicina - Universidade Federal de São Paulo (Unifesp) - São Paulo, SP, Brasil. 4. Professora Associada do Departamento de Ginecologia da Escola Paulista de Medicina - Universidade Federal de São Paulo (Unifesp) - São Paulo, SP, Brasil.
\end{abstract}

\section{SUMMARY}

Additive Manufacturing (AM), also known as Rapid Prototyping, is a set of production technologies used in the synthesis of a particular physical object by adding layers to form a part based on data generated by Computer-Aided Design (CAD) systems. These technologies are widely used to quickly create prototypes of products and tools for commercial purposes. Over time, it has also been integrated with other areas, such as healthcare, since these tools have allowed health professionals to assist in diagnoses, surgical planning, and synthesis of orthoses and prostheses for patient rehabilitation.

OBJECTIVE: To develop models for the construction of dilators for the treatment of vaginal agenesis.

METHODS: Use CAD software and create a physical model using AM to analyze the viability of its production in the elaboration of customized dilators for each patient.

RESULTS: The production through AM provides an advantage in the development, facilitating physical alterations just by adjusting the three-dimensional models made by the software in a quick way, thus making the customization process viable.

CONCLUSION: The proposed procedure for the manufacture of dilators presented good results and technological feasibility, indicating that it can be a good solution for the production and customization of gynecological devices.

KEYWORDS: Vagina/abnormalities. Gynecology. Printing, Three-Dimensional. Dilatation/instrumentation.

\section{INTRODUCTION}

\section{Vaginal agenesis}

Vaginal agenesis is a congenital malformation of the reproductive tract of women caused by an anomaly in the formation of the paramesonephric ducts (Müller), responsible for originating the internal genital organs in females ${ }^{1.2}$.

Most vaginal agenesis cases are related to the Mayer-Rokitansky-Kuster-Hauser (MRKH) syndrome, characterized by complete müllerian agenesis. Its incidence ranges from 1 for every 4,000/5,000 live births of females, and its identified by the congenital absence of the uterus and the superior $2 / 3$ of the vagina'.

The diagnosis can be made by a simple physical examination, but it can be evidenced since birth by the examination of the genitals. Usually, the

DATE OF SUBMISSION: 09-Jul-2020

DATE OF ACCEPTANCE: 11-Jul-2020

CORRESPONDING AUTHOR: Thyeres Teixeira Bueno Chrispin

Departamento de Ginecologia - Unifesp - Rua Napoleão de Barros, 638, Vila Clementino, São Paulo, SP, Brasil - $04024-002$

Tel: +55 1198436-4366

E-mail: thyeres.unifesp@gmail.com 
diagnosis is established during adolescence, when the patient seeks assistance due to complaints of absent menstruation and/or difficulty in sexual intercourse ${ }^{3}$.

Faced with these facts, a multidisciplinary approach is required from the beginning of the treatment, with a joint action of medical, psychological, nursing, technological, and physical therapy teams ${ }^{3}$.

Despite the rare incidence of this condition, its treatment has been widely discussed and studied. Currently, the conservative method has been considered the first-line treatment, for obvious reasons (low rate of complications, ease of implementation, low cost). This treatment is based on creating a vaginal canal neoformed from the progressive dilation of the vaginal introitus using acrylic dilators. This method was developed by Frank in 1938, and modified by Ingram in $1981^{4.5}$.

In 2013, the American Congress of Gynecology and Obstetrics recommended vaginal dilation as the first-line treatment for vaginal agenesis. This technique also is the technique of choice in several other countries such as the United Kingdom, Australia, the United States, and Russia. Vaginal dilation as the firstline treatment for vaginal agenesis has the benefit of being a safer technique, in addition to presenting a significant success rate ${ }^{6}$.

The main purpose of the vaginal dilators is to promote the dilation and awareness of the pelvic floor muscles in women with any dysfunction in this area. These devices vary in size and thickness, something important for the treatment, which is progressive in nature ${ }^{7}$.

Kits sold commercially, in general, contain six penetrators made of silicone, their surface is smooth and their sizes vary from $1.2 \mathrm{~cm}$ to $4 \mathrm{~cm}$ in diameter and from $6.5 \mathrm{~cm}$ to $14.5 \mathrm{~cm}$ in length; however, devices made of silicone are not fitting for vaginal agenesis cases because they are too flexible. The more rigid models are not sold in Brasil.

Typically, these dilators come in specific and standardized lengths and diameters, which may hinder their use in different patients, making it necessary to have a custom-made model, on a case by case basis.

$\mathrm{AM}$, better known as 3D printing, is a manufacturing process based on the creation of a physical object by adding layers of a certain material, using data generated by a mechanical design software that uses $C A D$ (Computer-Aided Design) technology ${ }^{7-9}$.

These technologies are widely used for quickly creating prototypes, products, and tools for commercial purposes ${ }^{10}$.

The most common and widely known 3D printers have as their basic physical principle the fusion and extrusion of thermoplastic materials and deposition of such material in layers until the desired object is formed. This method is known as FDM (Fused Deposition Modeling) ${ }^{11}$.

A characteristic feature of 3D printers is their ability to create an object using a digital drawing in a type of software capable of reading the entire surface of the object drawn. The most widely known file format for reading CAD drawings is STL (Stereo Lithography).

Among the health areas in which MA is used most prominently, currently, are surgical aid tools, tools for aiding physicians in exams or procedures, orthopedic implants and prostheses. This field also presents great research possibilities regarding the creation of new technologies and, consequently, a breakthrough in healthcare ${ }^{12}$.

Particularly among women with vaginal agenesis, the creation of custom vaginal dilators can be an excellent alternative treatment. Each patient could benefit from the creation of dilators in custom sizes and formats to fit their anatomy. Thus, based on the evolution of treatment, new Dilators could be designed according to the needs of each patient ${ }^{13}$.

Therefore, AM could contribute to the development of these devices, meeting the specific needs of each patient and providing more individualized care.

\section{OBJECTIVE}

Prepare digital models for building custom dilators for the treatment of vaginal agenesis by additive manufacturing.

\section{METHODS}

The preparation of the procedure for the development of the devices was divided into five steps:

\section{Survey of the requirements and assessment} of the parameters of use

In order to specify the requirements for the development of a prototype, we conducted a survey with gynecology professionals and on the devices already on the market to obtain information on the characteristics, dimensions, and parameters (ergonomic and geometric) required to produce the dilators. 


\section{Development of the model using a CAD} software

The modeling of the prototypes was done using the 3D parametric modeling software AutoCAD and FreeCAD based on the requirements previously defined.

\section{Manufacturing of the dilators by Additive}

\section{Manufacturing}

The production of the devices was done using the 3D printer Cube, developed by the company 3D Systems, using polymeric polylactic acid (PLA) filaments.

4. Analysis of the quality of the dilators produced

After the device was manufactured by the 3D printer, the piece went through a quality check to verify its mechanical resistance, geometrical structure and whether the physical object produced had the characteristics determined during the modeling step.

5. Analysis of the devices by a team of professionals

To check if the prototype produced met all the requirements established, the device underwent an evaluation by three specialists in the area, who analyzed all aspects and assessed whether the device adequately met the defined needs. The experts were gynecologists from the Genital Malformation Unit of the Department of Gynecology of the Escola Paulista de Medicina, UNIFESP.

\section{RESULTS}

\section{Survey of the requirements}

Based on the analysis of products with similar systems and by carrying out discussion sessions with the members of the project and experts, three models of non-flexible dilators were established, measuring 12.0 $\mathrm{cm}, 10.0 \mathrm{~cm}$, and $8.0 \mathrm{~cm}$ in height and $2.5 \mathrm{~cm}, 2.0 \mathrm{~cm}$, and $1.5 \mathrm{~cm}$ in diameter, respectively, in addition to determining the ergonomic and geometric conditions for the devices, always taking into account their ability to be customized.

After the first model was developed and a discussion was carried out to ascertain whether the device met the specifications proposed by the professionals, it was concluded that changes on the top surface of the device were necessary to make it more rounded. These changes were carried out, and the device was taken again for evaluation by the group of professionals, who found that the modified device met the proposed specifications.

FIGURE 1. THREE-DIMENSIONAL MODELS DESIGNED USING MODELING SOFTWARE A

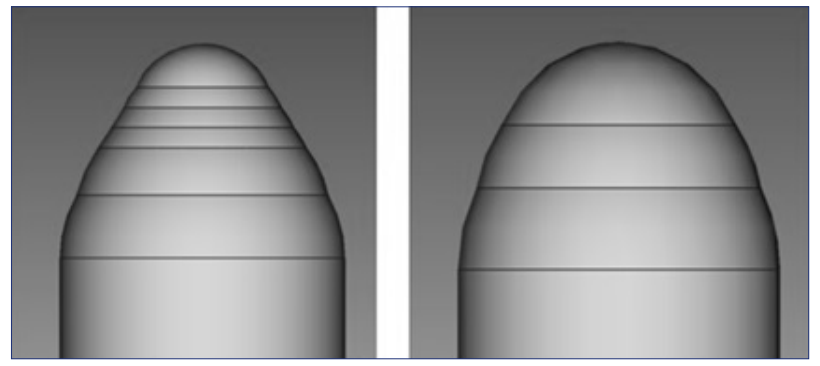

Author: Thyeres T. B. Chrispin

There modeling step in the CAD environment was adjusted according to the parameters collected from the previous model of the device that was commercially available. The data observed during the explanation of the use of the device substantially influenced the improvement of the geometric characteristics of the final three-dimensional model.

The software-based modeling produced designs that met the needs for the production of the device and the fundamental characteristics for it to perform the specific functions of the treatment.

FIGURE 2. THE FINAL THREE-DIMENSIONAL MODEL OF THE VAGINAL DILATOR

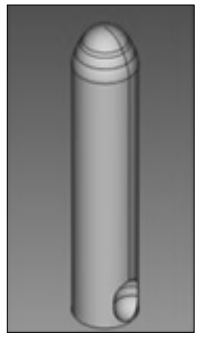

Author: Thyeres T. B. Chrispin

The process of creating the devices by AM was completed as expected, resulting in the production of pieces per the requirements established in the first stage, with a dimensional accuracy of up to $0.2 \mathrm{~mm}$, a variation that does present problems for customization or the treatment. 


\section{Quality of the dilators}

AM proved to be a viable system for manufacturing dilators. The polymers used showed good mechanical resistance in different settings. The dimensional stability remained constant and the constancy of the dimensional repeatability also presented results as expected.

\section{Professional opinion}

According to the assessment by the professionals, the dilator met the objective proposed without failure, ie., the prototype has all the characteristics to meet the requirements proposed in the first step and that allow it to perform the procedures for the treatment of vaginal agenesis.

FIGURE 3. DILATOR MODELS PRODUCED BY 3D PRINTING

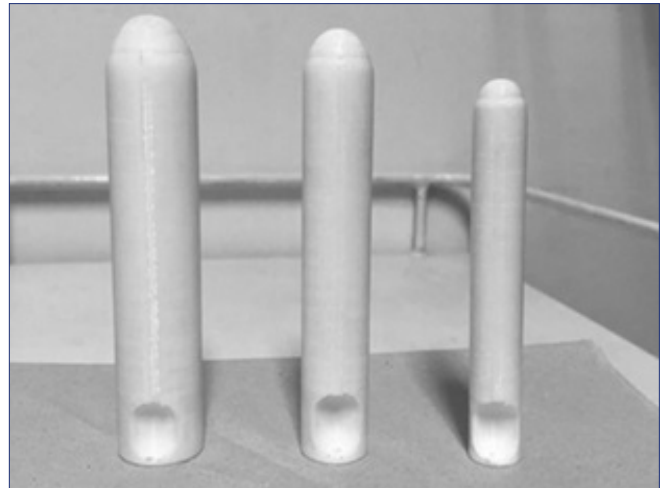

Author: Thyeres T. B. Chrispin

\section{DISCUSSION}

The ergonomics, thickness, and length of a vaginal dilator are directly related to the anthropometric measures of its user.
The existing dilators, despite their variation in the INTERROGATORIES length and thickness, probably there would meet all the characteristics of ergonomics are necessary.

During the process of modeling using CAD software, it was possible to produce designs that met the requirements specified by the professionals, and it was proven that the customization of models using the software is perfectly possible, resulting in models that are adequate to the ergonomic characteristics of each person.

The drawings are saved in STL will remain stored in the system of the Department of Gynecology of Unifesp so that, in the future, they can be shared, through an app or via the web, with other health professionals.

Production using AM presented an advantage in the development, making it easier to implement physical changes only by quickly adjusting the 3D models made by software, making the process of customization viable.

The next step in this study is to check with the specialists the effectiveness of the dilators produced by AM, as well as investigate the possibility of custom care by using this technology.

\section{CONCLUSION}

The proposed procedure for the manufacturing of the dilators showed good results and technological feasibility, indicating that it may be a good solution for the production and customization of gynecological devices.

AM technology by thermofusion and its accuracy have met the specific needs of the study. Now, new studies are required related to its feasibility in treatments with monitoring by professionals in the area.

\section{RESUMO}

A Manufatura Aditiva (MA), também conhecida como Prototipagem Rápida, é um conjunto de tecnologias de produção utilizado na síntese de determinado objeto físico por meio da adição de camadas para formar uma peça com base em dados gerados por sistemas de projeto auxiliado por computador (CAD - Computer Aided Design). Essas tecnologias são muito utilizadas para criação de protótipos de produtos e ferramentas de maneira rápida para fins comerciais. Com o tempo, também se integrou a outras áreas, como a área da saúde, uma vez que essas ferramentas permitiram auxiliar o profissional da saúde em diagnósticos, planejamento cirúrgico e na síntese de órteses e próteses para reabilitação de pacientes.

OBJETIVO: Elaborar modelos computadorizados para a construção de dilatadores para tratamento de agenesia vaginal pela impressão 3D. MÉTODO: Utilização de software CAD e criação do modelo físico por meio de MA para análise da viabilidade de sua produção na elaboração de dilatadores customizados para cada paciente. 
RESULTADOS: A produção por meio de MA atribui uma vantagem ao desenvolvimento, facilitando as alterações físicas apenas ajustando os modelos tridimensionais feitos pelos softwares de maneira rápida, tornando o processo de customização viável.

CONCLUSÃO: O procedimento proposto para a fabricação dos dilatadores apresentou bons resultados e viabilidade tecnológica, indicando que pode ser uma boa solução de produção e customização de dispositivos ginecológicos.

PALAVRAS-CHAVE: Vagina/anormalidades. Ginecologia. Impressão tridimensional. Dilatação/instrumentação.

\section{REFERENCES}

1. Gutsche RM, Chagas LA, Leal R, Cunha AL, Djahjah MCR. Síndrome de Mayer-Rokitansky-Kuster-Hauser: relato de caso e revisão da literatura. Radiol Bras. 2011;44(3):192-4.

2. Maia H. Más-formações genitais. In: Histerosalpingografia: introdução ao estudo da radiologia ginecológica. Salvador: EDUFBA;2009. p.75-96.

3. Abbe R. New method of creating a vagina in a case of congenital absence. Med Rec. 1898;54:836-8.

4. Goldwyn RM. History of attempts to form a vagina. Plast Reconstr Surg 1977;59(3):319-29.

5. Fedele L, Busacca M, Candiani M, Vignali M. Laparoscopic creation of a neovagina in Mayer-Rokitansky-Küster-Hauser syndrome by modification of Vecchietti's operation. Am | Obstet Gynecol. 1994;171(1):268-9.

6. Edmonds DK, Rose GL, Lipton MG, Quek |. Mayer-Rokitansky-Küster-Hauser syndrome: a review of 245 consecutive cases managed by a multidisciplinary approach with vaginal dilators. Fertil Steril. 2012;97(3):686-90.

7. McQuillan SK, Grover SR. Dilation and surgical management in vaginal agenesis: a systematic review. Int Urogynecol J. 2014;25(3):299-311.
8. Weigert MC, Foggiatto JA. Tecnologias de escaneamento 3D e de prototipagem rápida aplicadas no desenvolvimento de produtos customizados [Internet]. XVII Seminário de Iniciação Científica e Tecnológica da UTFPR. Curitiba: Universidade Tecnológica Federal do Paraná; 2012.

9. Azevedo FM. Estudo e projeto de melhoria em máquina de impressão 3D [Trabalho de Conclusão de Curso]. São Carlos: Escola de Engenharia de São Carlos, Universidade de São Paulo; 2013.

10. Weigert MC, Foggiatto |A. Tecnologias de escaneamento 3D e de prototipagem rápida aplicadas no desenvolvimento de produtos customizados. XVII Seminário de Iniciação Científica e Tecnológica da UTFPR. Curitiba: Universidade Tecnológica Federal do Paraná; 2012.

11. Carvalho |, Volpato N. Prototipagem rápida como processo de fabricação. In: Ahrens CH, Ferreira CV, Petrush G, Carvalho J, Santos JRL, Silva JVL, eds. Prototipagem rápida: tecnologias e aplicações. São Paulo: Blücher; 2007.

12. Silva JVL, Dias PEM, Fernandes CMS, Serra MC, Sperling DM, Fecchio RS, et al. Aplicações da AM em áreas diversas. In: Volpato N, org. Manufatura aditiva: tecnologias e aplicações da impressão 3D. São Paulo: Blucher; 2017.

13. Martins KYN, Branco RRC, Andrade KD, Silva JB, Oliveira MLF. Desenvolvimento de um educador vaginal através do processo de manufatura aditiva (impressão 3D). Rev Pesq Fisioterapia. 2017;7(1):20-3. 